\title{
THE EFFECT OF PHYSICO-CHEMICAL VARIATIONS ON PHYTOPLANKTON STATUS IN THE MARGIN OF CHOGHAKHOR WETLAND, IRAN
}

\author{
DeHghani, I. ${ }^{1}-$ PEYKANPOURFARD, P. ${ }^{2,3 *}-$ DANIALI, S. R. ${ }^{4}$

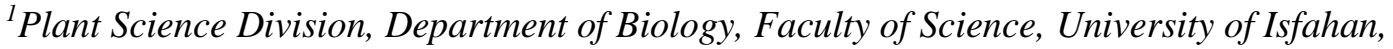 \\ Isfahan, Iran \\ (phone: +98-91-3904-1386; fax: +98-31-3793-2456) \\ ${ }^{2}$ Human Environment and Sustainable Development Research Center, Najafabad Branch, \\ Islamic Azad University, Najafabad, Iran \\ ${ }^{3}$ Department of Environmental Management, Najafabad Branch, Islamic Azad University, \\ Najafabad, Iran \\ ${ }^{4}$ Isfahan Department of Environment, Isfahan, Iran \\ *Corresponding author \\ (e-mail:Peykanpour@phu.iaun.ac.ir; active e-mail:Idehghani2018@gmail.com; phone: +98- \\ 91-3115-1501; fax: +98-31-3268-4856) \\ (Received $17^{\text {th }}$ Oct 2018; accepted $2^{\text {nd }}$ Jan 2019)
}

\begin{abstract}
Many human activities in the margin of Choghakhor wetland, (Iran) causes evaluation of the phytoplankton status in relation to the physico-chemical parameters in different seasons of 2011 in 5 marginal stations of the wetland. Water samples prepared in triplicate and temperature, $\mathrm{pH}$, dissolved oxygen, nitrate and phosphate concentration were measured using APHA methods. The phytoplankton identified, counted and Shannon diversity index $\left(\mathrm{H}^{\prime}\right)$. Phytoplankton community included 59 genera, 43 families and 6 divisions, among which Bacillariophyta was the most common (46.6\%) followed by Chlorophyta (32.0\%), Cyanophyta (13.3\%), Dinophyta (4.4\%), Euglenophyta (3.0\%) and Chrysophyta $(0.8 \%)$. Phytoplankton density, nitrate, and phosphate concentration were different in different stations and seasons $(\mathrm{P}<0.05)$. The highest density was recorded for Nitzschia followed by Cosmarium, Microcystis, Peridinium, Euglenaria and Dinobryon. Also, Microcystis density was maximum in station 5 [S5]. There were significant correlations between the phytoplankton density and nitrate concentration $(\mathrm{r}=0.6, \mathrm{P}<0.01)$, Chlorophyta and phosphate concentration $(\mathrm{r}=0.3, \mathrm{P}<0.01)$, Cyanophyta and phosphate concentration $(\mathrm{r}=0.2, \mathrm{P}<0.05)$. Although wetland water was still clean $\left(\mathrm{H}^{\prime}>3\right)$, high density of Nitzschia and Microcystis as eutrophication bio-indicators showed starting of eutrophication. Microcystis as the most abundant genus of Cyanophyta must be seriously controlled to avoid blooms in the wetland.
\end{abstract}

Keywords: phytoplankton composition, physico-chemical parameters, Choghakhor wetland, nitrate, phosphate

\section{Introduction}

The enrichment and pollution due to human activities are one of the most important environmental problems in wetlands that cause serious risks and may damage their fauna and flora (Rosińska et al., 2017). Land use and human activities lead to entry of chemicals from various resources including residential and industrial wastewater as well as agricultural runoffs to aquatic environments, especially wetlands (Chang, 1995; Khan and Ansari, 2005; Bressler and Paul, 2018). These compounds mainly contain high concentrations of nitrogen and phosphorus (Fonge et al., 2012) and could affect 
physicochemical characteristics and quality of water as well as the bio-communities of the wetlands. These effects vary in different ecosystems. For example, different studies have shown that increase of agricultural and residential wastewater inputs to wetlands causes changing water quality, variation in growth of phytoplankton communities, decrease water dissolved oxygen and ultimately an eutrophication status and elimination of the wetlands (Paludan et al., 2002; Sakset and Chankaew, 2013; Stević et al., 2018; Zhang, 2018). Hence, it is necessary to evaluate the growth of phytoplankton biocommunities in the wetlands exposed to agricultural and residential pollutants to control the effects of the pollutants and to preserve and maintain their life (Khan and Ansari, 2005).

Phytoplankton as photosynthetic organisms are the major producer especially in deep water as well as are the base of food chain in aquatic ecosystems (Muhammad et al., 2005). Other aquatic organisms are dependent on the phytoplankton directly and indirectly (Kelly, 1998; Moss, 2009; Jones et al., 1996). The production levels of phytoplankton maximizes when the water physicochemical characteristics are at optimum levels (Sinha and Srivastava, 1991; Muhammad et al., 2005; Sahu et al., 2012). Therefore, the composition of phytoplankton communities is a bio-indicator for the quality of lake water (Peerapornpisal et al., 2004; Wu et al., 2014; Sakset and Chankaew, 2013; Bellinger and Sigee, 2015).

The communities of the phytoplankton in freshwater ecosystems such as wetlands and lakes are mainly composed of Chlorophyta (green algae), Cyanophyta (blue-green algae), Bacillariophyta (diatoms) and Dinophyta (Rosén, 1981; Eloranta, 1986; Sorayya et al., 2011). Also, growth, ecological distribution, presence and abundance of the phytoplanktonic communities are affected by numerous environmental factors especially changes in water quality or mineral nutrients (Stević et al., 2018; Zhang, 2018). Algal blooms, especially in Cyanophyta and Dinophyta, is the main problems due to the excessive inputs of organic and inorganic compounds -such as agricultural fertilizers and pesticides- to aquatic environments (Rosińska et al., 2017). It causes to unfavorable taste and odor of water as well as destruction of organisms due to toxic substances produced by this phytoplankton (Fonge et al., 2012).

International wetland of Choghakhor is one of the most important water bodies in Iran, have different capabilities as valuable habitat for birds as written by Ramsar convention (Ebrahimi and Moshari, 2006). Nowadays, this wetland is affected by human activities especially agriculture runoffs and residential wastewaters (Nadushan and Fatemi, 2008; Samadi, 2016). Due to the obvious effects of human activity on the excessive phytoplankton abundance and its deleterious effects on biology of aquatic ecosystems (Chang, 1995; Khan and Ansari, 2005; Bressler and Paul, 2018), in this study the phytoplankton status involving density, composition, diversity as well as spatial / temporal distribution in relation to physico-chemical changes were evaluated in different seasons of 2011 as well as different stations designated in the margin of Choghakhor wetland.

\section{Materials and methods}

\section{Description of study area}

Choghakhor wetland is located on the Gondman district, Boroojen city in the province of Chahar-Mahal-Bakhtiari, Iran. This province is located on the southwest part of Iran which is near Zagros Mountains. This area extended 1500 ha between $31^{\circ}$ 
$54^{\prime} 32^{\prime \prime} \mathrm{N}$ to $31^{\circ} 56^{\prime} 32^{\prime \prime} \mathrm{N}$ and $50^{\circ} 53^{\prime} 58^{\prime \prime} \mathrm{E}$ to $50^{\circ} 56^{\prime} 09^{\prime \prime} \mathrm{E}$, with an average altitude of $2400 \mathrm{~m}$ above sea level (Ebrahimi and Moshari, 2006). Choghakhor is a permanent shallow lake by an average depth of $2 \mathrm{~m}$. Rainfall occurs at spring (mid-March) and fall (mid-October) with the mean annual rainfall of $380 \mathrm{~mm}$.

In the southern part of the wetland, the villages of Sangchin, Avorgan, Sibak, Dastgerd, Khaniabad, Sakiabad, Khedrabad and Galugerd are located from east to west, respectively. Recent human activities in the vicinity of the Choghakhor wetland have caused to increase agricultural runoffs and residential wastewaters, especially at its southern and western parts (Samadi, 2016).

\section{Determination of sampling stations}

The location of sampling stations was selected on topographic map considering the aim of the study in the margin of the wetland at different coordinates (Table 1; Fig. 1). Although Chaghakhor is a uniform lake with a steady slope (Ebrahimi and Moshari, 2006), entire environment of the lake was evaluated during the sampling period and 5 stations were selected, eventually. It was assumed that the selected station represented the surrounding area (Table 1).

Table 1. Coordinates of sampling stations (S1 - S5) in Choghakhor wetland

\begin{tabular}{c|c}
\hline Station & Coordinate (degree -minute -second) \\
\hline S1 & $50^{\circ} 52^{\prime} 51.49^{\prime \prime} \mathrm{E}, 31^{\circ} 55^{\prime} 49.27^{\prime \prime} \mathrm{N}$ \\
S2 & $50^{\circ} 54^{\prime} 12.20^{\prime \prime} \mathrm{E}, 31^{\circ} 56^{\prime} 11.14^{\prime \prime} \mathrm{N}$ \\
S3 & $50^{\circ} 52^{\prime} 58.36^{\prime \prime} \mathrm{E}, 31^{\circ} 45^{\prime} 51.88^{\prime \prime} \mathrm{N}$ \\
S4 & $50^{\circ} 55^{\prime} 54.52^{\prime \prime} \mathrm{E}, 31^{\circ} 55^{\prime} 07.84^{\prime \prime} \mathrm{N}$ \\
S5 & $50^{\circ} 56^{\prime} 05.69^{\prime \prime} \mathrm{E}, 31^{\circ} 55^{\prime} 17.24^{\prime \prime} \mathrm{N}$ \\
\hline
\end{tabular}

\section{Sample collection}

Sampling was done in 1 liter Teflon bottles at a depth of $50 \mathrm{~cm}$ at five stations with 3 biological replicates in spring (May), summer (August), fall (October) and winter (December) seasons in 2011.

First, the sampling containers were washed with the wetland water (three times) to accurate measurement of physicochemical properties of water. Then, the one set of the collected samples were transferred to the laboratory under standard conditions to evaluate some physicochemical properties of water using American Public Health Association [APHA] standard methods (Amy et al., 1992) (Fig. 2). The water temperature (thermometer; HANNA, PHep 4 HI98127, USA), pH (pH-meter; JENWAY3330, Canada), dissolved oxygen (DO-meter; Pro20 Dissolved Oxygen Instrument, Xylem, Japan) as well as the nitrate and phosphate concentration (spectrophotometer; Hach- DR 2400, USA) were measured based on the instruments manual.

Other set of the collected samples were used for phytoplankton assessment. These samples were fixed with three drops of Lugol's solution $(0.007 \mathrm{v} / \mathrm{v})$ in polyethylene containers $(250 \mathrm{ml})$ to easy identification and then were transferred to laboratory in a cooler packed with ice blocks. 


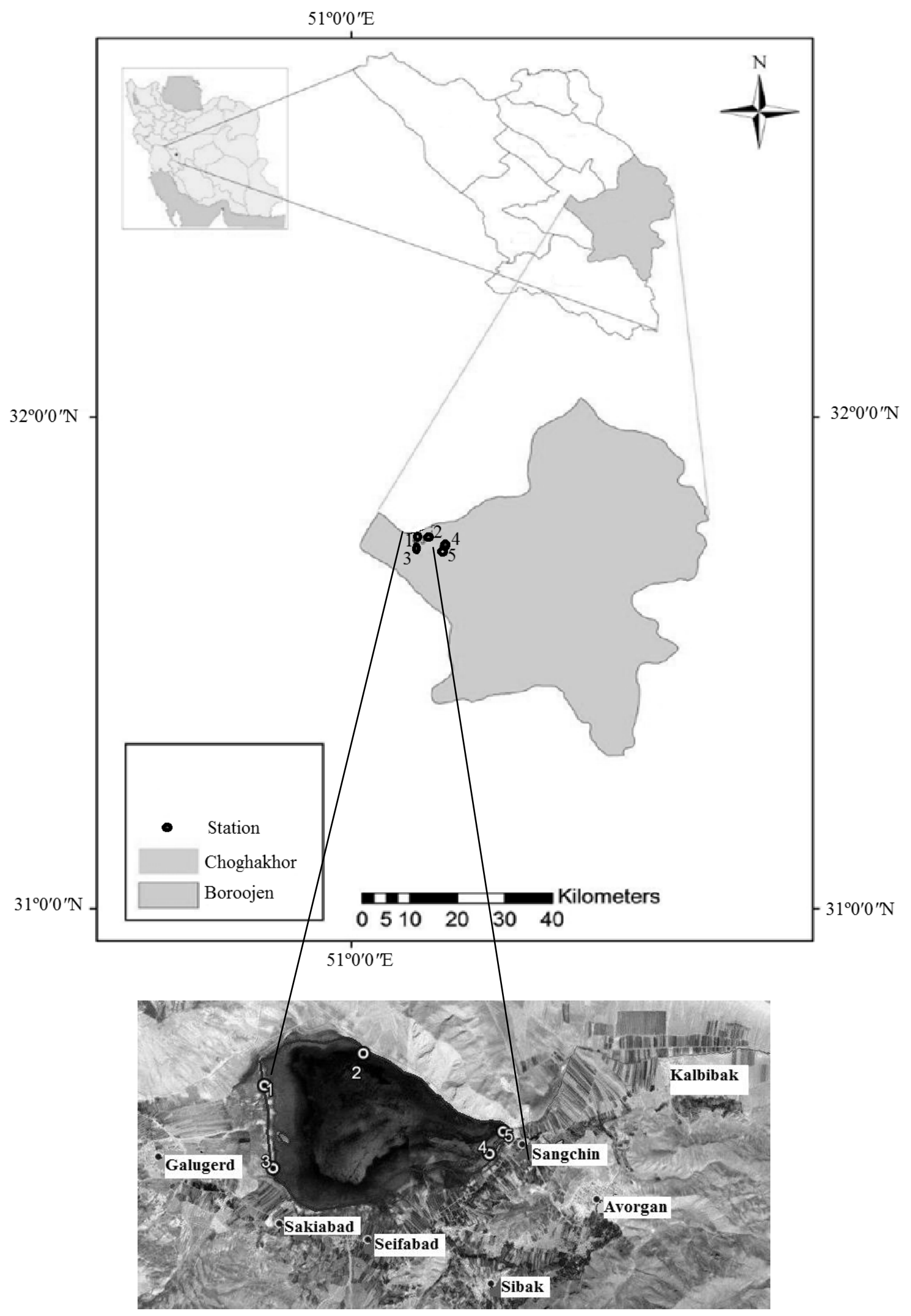

Figure 1. Location of sampling stations (S1-S5) in Choghakhor wetland (ArcMap 10.1). (N: north, E: east) 
A

$$
\text { 重: }
$$
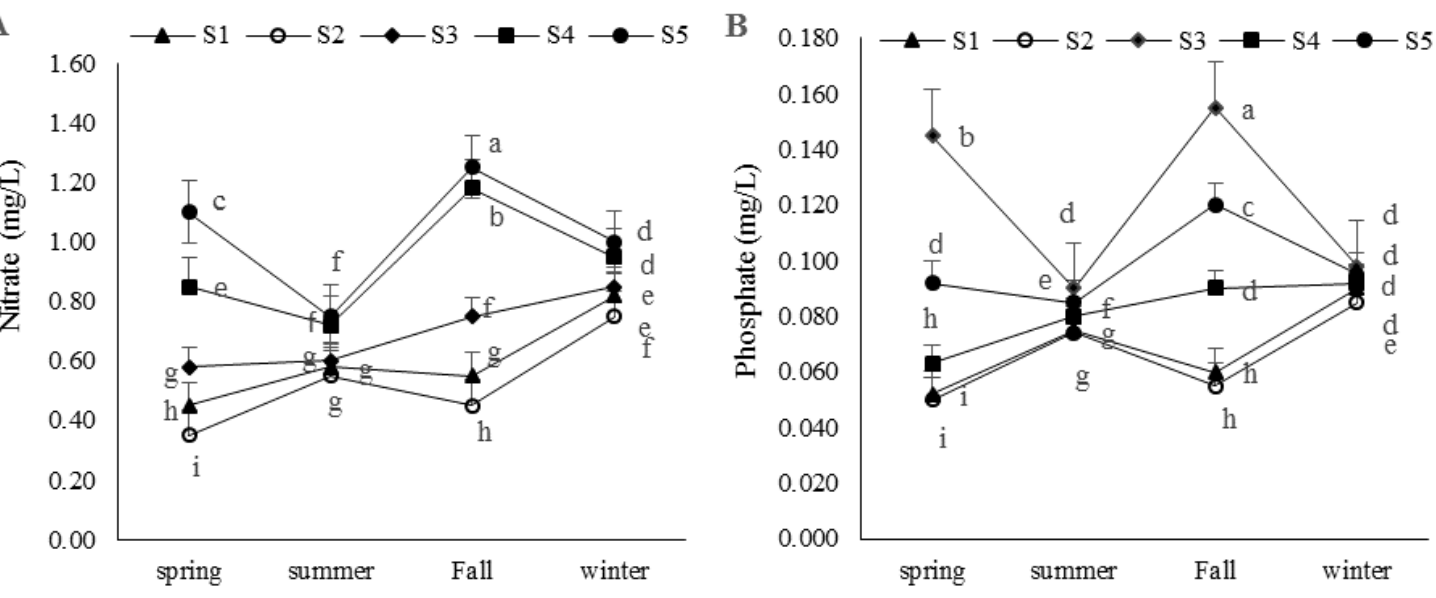

C

C 10.0

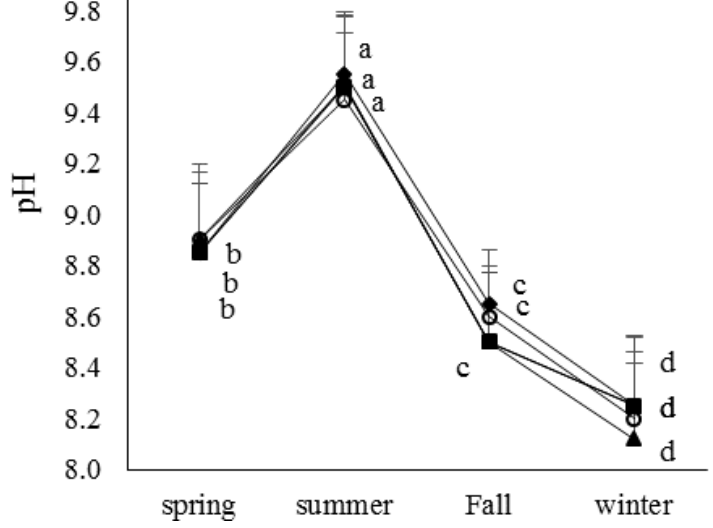

D
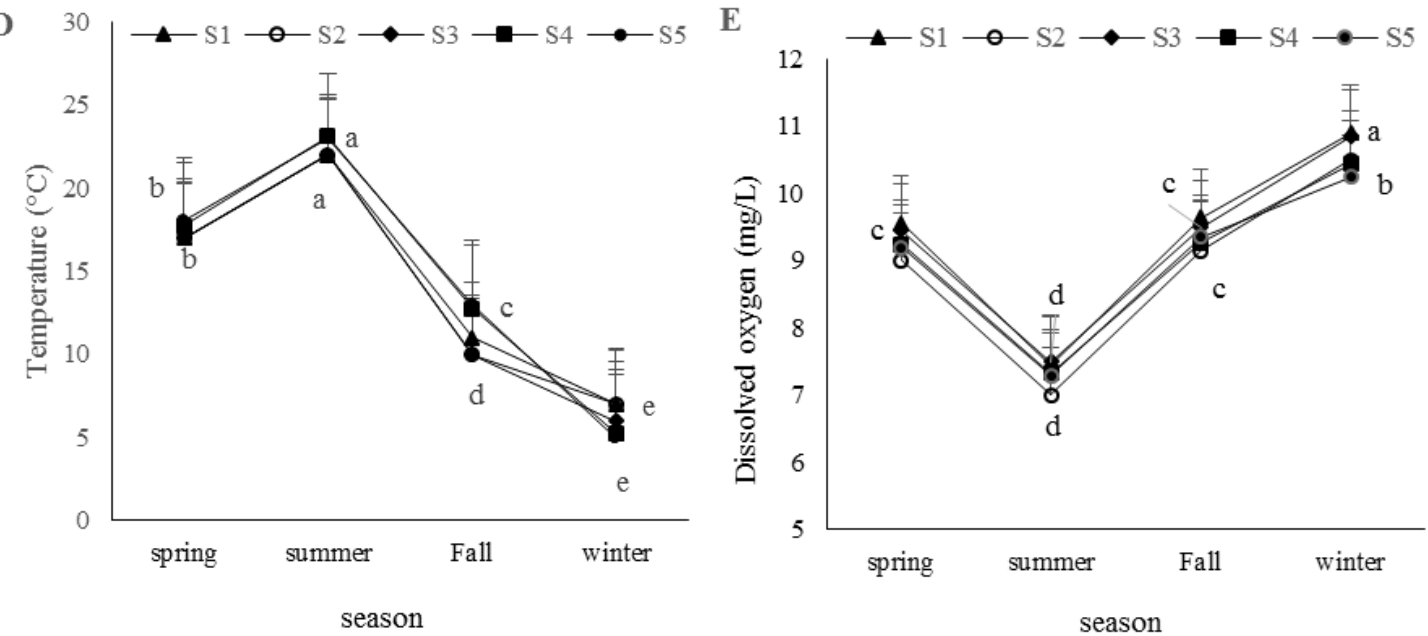

Figure 2. Physico-chemical parameters of water in different seasons and stations (S1-S5) in Choghakhor wetland. Data represent the means values $\pm S E(n=3)$. Different letters in the mean values indicate difference between the means based on Duncan's multiple range tests,

$$
P<0.05
$$

\section{Identification, count and diversity of phytoplankton}

The genera of phytoplankton were identified using binocular optical microscope (Olympus CH20i, Japan) with a magnification of 1000x (with emersion oil) and the 
related text books and papers (Krammer and Lange-Bertalot, 1986; Bellinger and Sigee, 2015). To count and measure the phytoplankton density, $1 \mathrm{ml}$ from each sample were evaluated using Sedgwick rafter slides (Wildco 1801-A10, JA Whitlock \& Co, Australia) with three technical replicates.

The Shannon diversity index $\left(\mathrm{H}^{\prime}\right)$ was calculated (Eq. 1):

$$
\mathrm{H}^{\prime}=\sum \mathrm{P}_{\mathrm{i}} * \ln \mathrm{P}_{\mathrm{i}}
$$

Where $\mathrm{P}_{\mathrm{i}}$ is proportion of total sample belonging to $i^{\text {th }}$ genus and $i$ is the number of genera (Magurran, 1988).

\section{Statistical analysis}

Data analysis were done using One-way ANOVA (SPSS21) and the mean values were compared using Duncan's multiple range tests at $95 \%$ confidence interval $(\mathrm{P}<0.05)$. Pearson correlation coefficient was used to evaluate the correlations between physicochemical parameters of water and phytoplankton density and diversity.

\section{Results}

\section{Physico-chemical parameters}

Physicochemical characteristics of Choghakhor wetland are given in Figure 2.

\section{Nitrate}

In average, nitrate concentration $(\mathrm{mg} / \mathrm{L})$ were different $(\mathrm{P}<0.05)$ in different seasons and stations (Fig. 2A). High amount of nitrate was observed in S5 and then in S4, S3, S1 and $\mathrm{S} 2$ respectively. Nitrate concentration in $\mathrm{S} 2$ and $\mathrm{S} 1$ decreased from the spring to winter. However, maximum concentration of nitrate was measured in S4 and S5 in the fall as well as the minimum in $\mathrm{S} 2$ in the spring (Fig. 2A).

\section{Phosphate}

Phosphate concentrations $(\mathrm{mg} / \mathrm{L})$ average in different season and stations were significantly different $(\mathrm{P}<0.05)$ (Fig. 2B). Phosphate in different stations varied as: S3 $>\mathrm{S} 5>\mathrm{S} 4>\mathrm{S} 2 \approx \mathrm{S} 1$. In $\mathrm{S} 3$, phosphate was highest in the fall and then varies as: spring $>$ winter $\approx$ summer. In S5, phosphate was respectively highest in the fall followed by the spring or winter and lastly summer. Also, phosphate in S2 was maximum in the summer, afterward it was higher in the winter, fall and spring, respectively. The maximum concentration of phosphate was measured in S3 in the spring and fall $(0.155$ and 0.145 , respectively) and the minimum ones (0.050) in $\mathrm{S} 2$ in the spring (Fig. 2B).

$p H$

Different stations had the same $\mathrm{pH}$ but, the seasons showed different $\mathrm{pH}(\mathrm{P}<0.05)$. $\mathrm{pH}$ was 9.55 in the summer and 8.12 in the winter by an average $\mathrm{pH}$ of 8.78 . The wetland water is completely alkaline throughout the year (Fig. 2C). 


\section{Water temperature}

The results showed that the annual water temperature was $14{ }^{\circ} \mathrm{C}$ in average. Water temperature in different season was significantly different $(\mathrm{P}<0.05)$ but there were no significant difference between the studied stations. The maximum and minimum temperatures were measured in the summer and winter, respectively (Fig. 2D).

\section{Dissolved oxygen}

The concentration of water dissolved oxygen varies from 7 to $10.9 \mathrm{mg} / \mathrm{L}$. Only, dissolved oxygen was different in different stations in the winter, as S1, S2 and S3 were different from S4 and S5. Also, different seasons had different dissolved oxygen (except for spring and fall) as it was maximum in the winter and minimum in the summer. There were observed a reverse trend for temperature and dissolved oxygen variations $(-0.7, \mathrm{P}<$ 0.01) (Fig. 2E).

\section{Identification of the phytoplankton}

In this study, 59 genera belonging to 43 families and 6 divisions were identified (Table 2). Bacillariophyta was the most common phylum (46.6\%) with the most abundant number of genera followed by Chlorophyta (32.0\%), Cyanophyta (13.3\%), Dinophyta (4.4\%), Euglenophyta (3.0\%) and Chrysophyta (0.8\%) (Table 2). The most abundant genus was Nitzschia $(14.8 \%)$ belonging to Bacillariaceae family and Bacillariophyta phylum. The density and abundance of the genera in each division are given in Tables 3-6.

Table 2. The genera identified in the Choghakhor wetland

\begin{tabular}{|c|c|c|c|c|c|c|c|}
\hline Genus & Family & Phylum & $\mathbf{P}$ & Genus & Family & Phylum & $\mathbf{P}$ \\
\hline Ankistrodesmus & Selenastraceae & Chlorophyta & 1.2 & Amphora & Catenulaceae & Bacillariophyta & 0.9 \\
\hline Closterium & Closteriaceae & & 2.4 & Asterionella & Tabellariaceae & & 1.1 \\
\hline Cosmarium & Desmidiaceae & & 7.0 & Cocconeis & Cocconeidaceae & & 1.4 \\
\hline Desmodesmus & Scenedesmaceae & & 3.5 & Cyclotella & Stephanodiscaceae & & 6.2 \\
\hline Mougeotia & Zygnemataceae & & 2.4 & Cymatopleura & Surirellaceae & & 1.1 \\
\hline Oedogonium & Oedogoniaceae & & 1.2 & Cymbella & Cymbellaceae & & 0.6 \\
\hline Pediasterum & Hydrodictyaceae & & 1.2 & Denticula & Bacillariaceae & & 1.3 \\
\hline Staurastrum & Desmidiaceae & & 1.2 & Diatoma & Tabellariaceae & & 1.1 \\
\hline Scenedesmus & Scenedesmaceae & & 1.1 & Diploneis & Diploneidaceae & & 0.7 \\
\hline Spirogyra & Zygnemataceae & & 3.5 & Delicata & Gomphonemataceae & & 1.1 \\
\hline Staurodesmus & Desmidiaceae & & 1.2 & Epithemia & Rhopalodiaceae & & 0.6 \\
\hline Tetraedron & Chlorococcaceae & & 1.2 & Frustulia & Amphipleuraceae & & 1.0 \\
\hline Volvox & Volvocaceae & & 4.6 & Fragilaria & Fragilariaceae & & 1.4 \\
\hline $\begin{array}{l}\text { Zygnema } \\
\text { Total: }\end{array}$ & Zygnemataceae & & $\begin{array}{c}0.4 \\
32.0\end{array}$ & Gomphonema & Gomphonemataceae & & 1.5 \\
\hline Anabaena & Nostaceae & Cyanophyta & & Gyrosigma & Naviculaceae & & 0.8 \\
\hline Anacystis & Cyanophyceae & & 2.5 & Martyana & Fragilariaceae & & 0.9 \\
\hline Anathece & Synechococcaceae & & 2.3 & Melosira & Melosiraceae & & 1.2 \\
\hline Cyanoptyche & $\begin{array}{c}\text { Gloeochaetales familia } \\
\text { incertae sedis }\end{array}$ & & 0.4 & Navicula & Naviculaceae & & 0.8 \\
\hline Merismopedia & Merismopediaceae & & 0.3 & Nitzschia & Bacillariaceae & & 14.8 \\
\hline Microcystis & Microcystaceae & & 0.4 & Pinnularia & Pinnulariaceae & & 1.8 \\
\hline Nostoc & Nostocaceae & & 4.8 & Planothidium & Achnanthidiaceae & & 1.0 \\
\hline Oscillatoria & Oscillatoriaceae & & 0.4 & Tetracyclus & Tabellariaceae & & 0.9 \\
\hline Pseudanabaena & Pseudanabaenaceae & & 0.5 & Surirella & Surirellaceae & & 1.4 \\
\hline
\end{tabular}




\begin{tabular}{|c|c|c|c|c|c|c|c|}
\hline $\begin{array}{c}\text { Phormidium } \\
\text { Planktolyngbya }\end{array}$ & $\begin{array}{l}\text { Oscillatoriaceae } \\
\text { Leptolyngbyaceae }\end{array}$ & & $\begin{array}{l}0.2 \\
0.3\end{array}$ & $\begin{array}{c}\text { Synedra } \\
\text { Ulnaria } \\
\text { Total: }\end{array}$ & $\begin{array}{c}\text { Fragilariaceae } \\
\text { Ulnariaceae }\end{array}$ & & $\begin{array}{c}1.3 \\
1.7 \\
\mathbf{4 6 . 6}\end{array}$ \\
\hline $\begin{array}{l}\text { Rhabdogloea } \\
\text { Spirulina } \\
\text { Total: }\end{array}$ & $\begin{array}{c}\text { Synechococcaceae } \\
\text { Spirulinaceae }\end{array}$ & & $\begin{array}{c}0.4 \\
0.3 \\
\mathbf{1 3 . 3}\end{array}$ & $\begin{array}{c}\text { Ceratium } \\
\text { Glenodinium }\end{array}$ & $\begin{array}{c}\text { Ceratiaceae } \\
\text { Peridiniales incertae sedis }\end{array}$ & Dinophyta & $\begin{array}{l}0.6 \\
0.6\end{array}$ \\
\hline Euglenaria & Euglenaceae & Euglenophyta & 1.8 & $\begin{array}{l}\text { Peridinium } \\
\text { Total: }\end{array}$ & Peridiniaceae & & $\begin{array}{l}3.2 \\
4.4\end{array}$ \\
\hline Lepocinclis & Phacaceae & & 0.2 & Dinobryon & Dinobryaceae & Chrysophyta & 0.8 \\
\hline $\begin{array}{c}\text { Trachelomonas } \\
\text { Total: }\end{array}$ & Euglenaceae & & $\begin{array}{c}1.0 \\
\mathbf{3}\end{array}$ & 59 & 43 & 6 & $\mathbf{N}$ \\
\hline
\end{tabular}

$\mathrm{P}$ represents the abundance $(\%)$

Table 3. The density and abundance of identified genera belonging to Chlorophyta in the Choghakhor wetland. Data represent the means values $+S E(n=3)$

\begin{tabular}{c|c|c|c}
\hline No. & Genus & Density & Abundance (\%) \\
\hline 1 & Ankistrodesmus & $486 \pm 315$ & 4 \\
2 & Closterium & $969 \pm 635$ & 7 \\
3 & Cosmarium & $2869 \pm 1855$ & $\mathbf{2 2}$ \\
4 & Desmodesmus & $1435 \pm 951$ & 11 \\
5 & Mougeotia & $493 \pm 640$ & 7 \\
6 & Oedogonium & $478 \pm 318$ & 4 \\
7 & Pediasterum & $509 \pm 328$ & 4 \\
8 & Staurastrum & $435 \pm 280$ & 4 \\
9 & Scenedesmus & $1434 \pm 936$ & 3 \\
10 & Spirogyra & $481 \pm 308$ & 11 \\
11 & Staurodesmus & $476 \pm 307$ & 4 \\
12 & Tetraedron & $1866 \pm 1221$ & 4 \\
13 & Volvox & $168 \pm 116$ & 14 \\
14 & Zygnema & & 1 \\
\hline
\end{tabular}

Table 4. The density and abundance of identified genera belonging to Cyanophyta in the Choghakhor wetland. Data represent the means values $+S E(n=3)$

\begin{tabular}{c|c|c|c}
\hline No. & Genus & Density & Abundance (\%) \\
\hline 1 & Anabaena & $1021 \pm 363$ & 19 \\
2 & Anacystis & $925 \pm 405$ & 17 \\
3 & Anathece & $162 \pm 61$ & 3 \\
4 & Cyanoptyche & $142 \pm 77$ & 3 \\
5 & Merismopedia & $159 \pm 60$ & 3 \\
6 & Microcystis & $1969 \pm 714$ & $\mathbf{3 6}$ \\
7 & Nostoc & $220 \pm 97$ & 3 \\
8 & Oscillatoria & $97 \pm 42$ & 4 \\
9 & Pseudanabaena & $122 \pm 51$ & 2 \\
10 & Phormidium & $160 \pm 105$ & 2 \\
11 & Planktolyngbya & $127 \pm 94$ & 3 \\
12 & Rhabdogloea & $142 \pm 71$ & 2 \\
13 & Spirulina & & 3 \\
\hline
\end{tabular}


The genus Nitzschia with the density of $6054 \pm 1915$ cell/L (32\% abundance) was the most common in Bacillariophyta (Table 5). Also, Cosmarium $(2869 \pm 1855 \mathrm{cell} / \mathrm{L}$, $22 \%)$, Microcystis $(1969 \pm 714$ cell/L, 36\%), Peridinium $(1293 \pm 1310$ cell/L, 73\%), Euglenaria $(717 \pm 605$ cell/L, 59\%) were the most common genera in Chlorophyta, Cyanophyta, Dinophyta and Euglenophyta, respectively (Tables 3, 4 and 6). It was found only one genus from Chrysophyta named as Dinobryon with the density of $314 \pm 337$ cell/L (Table 6).

Table 5. The density and abundance of identified genera belonging to Bacillariophyta in the Choghakhor wetland. Data represent the means values $+S E(n=3)$

\begin{tabular}{|c|c|c|c|}
\hline No. & Genus & Density & Abundance (\%) \\
\hline 1 & Amphora & $360 \pm 115$ & 2 \\
\hline 2 & Asterionella & $432 \pm 138$ & 2 \\
\hline 3 & Cocconeis & $557 \pm 178$ & 3 \\
\hline 4 & Cyclotella & $2544 \pm 967$ & 13 \\
\hline 5 & Cymatopleura & $439 \pm 622$ & 2 \\
\hline 6 & Cymbella & $240 \pm 78$ & 1 \\
\hline 7 & Denticula & $517 \pm 165$ & 3 \\
\hline 8 & Diatoma & $439 \pm 141$ & 2 \\
\hline 9 & Diploneis & $301 \pm 97$ & 2 \\
\hline 10 & Delicata & $459 \pm 147$ & 2 \\
\hline 11 & Epithemia & $262 \pm 85$ & 1 \\
\hline 12 & Frustulia & $428 \pm 137$ & 2 \\
\hline 13 & Fragilaria & $573 \pm 183$ & 3 \\
\hline 14 & Gomphonema & $622 \pm 199$ & 3 \\
\hline 15 & Gyrosigma & $325 \pm 104$ & 2 \\
\hline 16 & Martyana & $367 \pm 118$ & 2 \\
\hline 17 & Melosira & $477 \pm 153$ & 3 \\
\hline 18 & Navicula & $317 \pm 102$ & 2 \\
\hline 19 & Nitzschia & $6054 \pm 1915$ & 32 \\
\hline 20 & Pinnularia & $743 \pm 237$ & 4 \\
\hline 21 & Planothidium & $401 \pm 128$ & 2 \\
\hline 22 & Tetracyclus & $379 \pm 122$ & 2 \\
\hline 23 & Surirella & $557 \pm 178$ & 3 \\
\hline 24 & Synedra & $520 \pm 166$ & 3 \\
\hline 25 & Ulnaria & $701 \pm 224$ & 4 \\
\hline
\end{tabular}

Table 6. The density and abundance of identified genera belonging to Dinophyta, Euglenophyta and Chrysophyta in the Choghakhor wetland. Data represent the mean values $+S E(n=3)$

\begin{tabular}{c|c|c|c|c}
\hline No. & Genus & Phylum & Density & Abundance (\%) \\
\hline 1 & Ceratium & Dinophyta & $246 \pm 242$ & 14 \\
2 & Glenodinium & & $243 \pm 245$ & 14 \\
3 & Peridinium & & $1293 \pm 1310$ & 73 \\
\hline 1 & Euglenaria & Euglenophyta & $717 \pm 605$ & 59 \\
2 & Lepocinclis & & $99 \pm 85$ & 9 \\
3 & Trachelomonas & & $389 \pm 325$ & 32 \\
\hline 1 & Dinobryon & Chrysophyta & $314 \pm 337$ & 100 \\
\hline
\end{tabular}




\section{Phytoplankton density}

The total phytoplankton density was seasonally and spatially different $(\mathrm{P}<0.05)$ (Fig. 3A). The density was highest in S5 in the fall (55563 cell/L) followed by spring (53788 cell/L) while it was the lowest in S2 in the spring (31922 cell/L) followed by S1 in the fall (31952 cell/L).

The phytoplankton community showed highest divergence in S4 and S5 in the summer and winter as well as in S4 in the spring and fall. The less diversity of the phytoplankton community was observed in the spring in S1 (Fig. 3B).
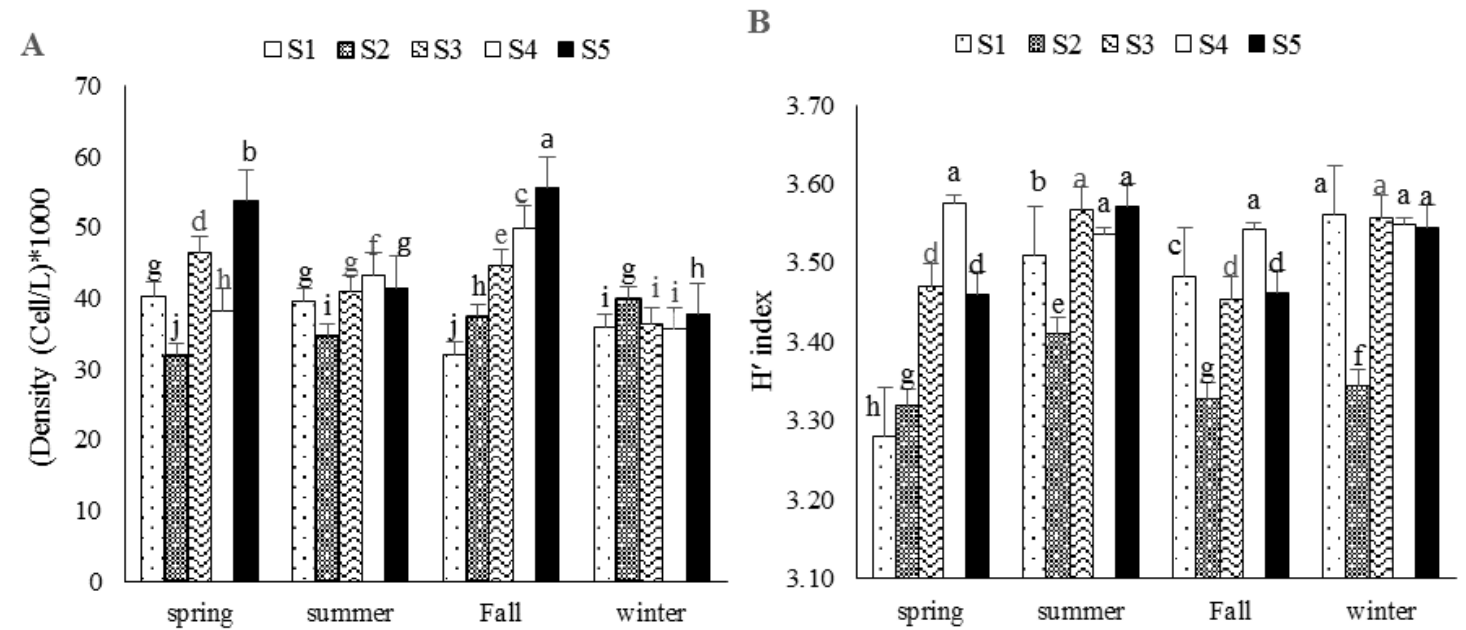

Figure 3. Total phytoplankton density $(A)$ and diversity ( $H^{\prime}$ index: Shannon diversity index) (B) in different seasons and stations (S1-S5) in the Choghakhor wetland. Different letters in the mean values indicated difference between the means based on Duncan's multiple range tests, $P<0.05$

The density of Chlorophyta, Cyanophyta, Bacillariophyta, Dinophyta, Euglenophyta and Chrysophyta were different in different seasons and stations (S1 - S5) in the wetland (P < 0.05) (Fig. 4). The density of Chlorophyta in S5 was highest ( $7756 \mathrm{Cell} / \mathrm{L})$ followed by S3, S4, S1 and S2 (5655 Cell/L), in the fall. Also, the density of Chlorophyta in $\mathrm{S} 2$ in the winter was highest followed by the summer, fall and spring while in S5 it was highest in the fall followed by spring, winter and lastly in the summer. The highest density of Cyanophyta was observed in S5 followed by S4, S3, S1 and S2, in the fall. In S5, Cyanophyta showed the maximum density in the fall and afterwards in the spring. Cyanophyta density in S2 in the fall was maximum and different from other seasons. Bacillariophyta density in S2 was more than the other stations $(\mathrm{S} 2>\mathrm{S} 1>\mathrm{S} 3 \approx \mathrm{S} 4>\mathrm{S} 5)$ and in it was highest in the spring $(\mathrm{P}<0.05)$. In $\mathrm{S} 2$, Bacillariophyta had the highest density in the fall and winter afterwards in the spring and summer. Bacillariophyta density in S3 and S5, in the summer and spring was greater than winter and fall.

In average, the highest and lowest density of Dinophyta was observed in S5 and S3, respectively. Dinophyta in the summer were most frequent than other seasons and they were not found in the winter in any stations. In the summer, the density of Dinophyta in S4 was highest and in S2 was at least. In the spring and fall, Dionophyta was found at maximum density in S5 and greater than S2 (Fig. 4). Euglenophyta and Chrysophyta in 
S5 and in the winter were more abundant than other stations (Fig. 4). The lowest density of Euglenophyta was observed in S2 and did not change during the year. Also, Chrysophyta in S2 and S1 were not found in any of the seasons.

A

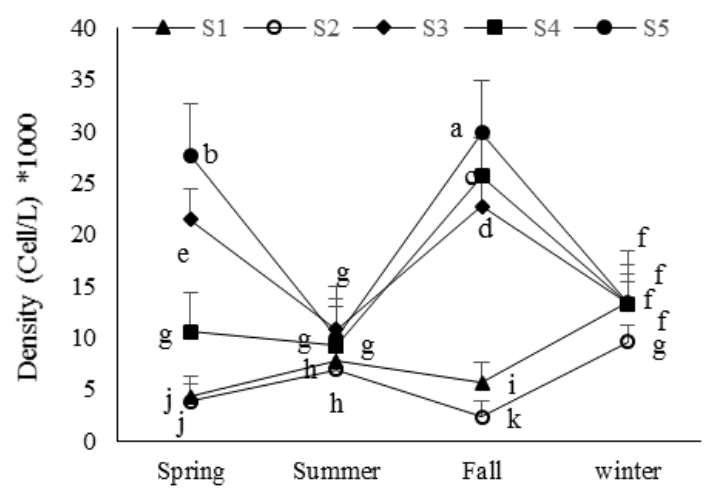

C

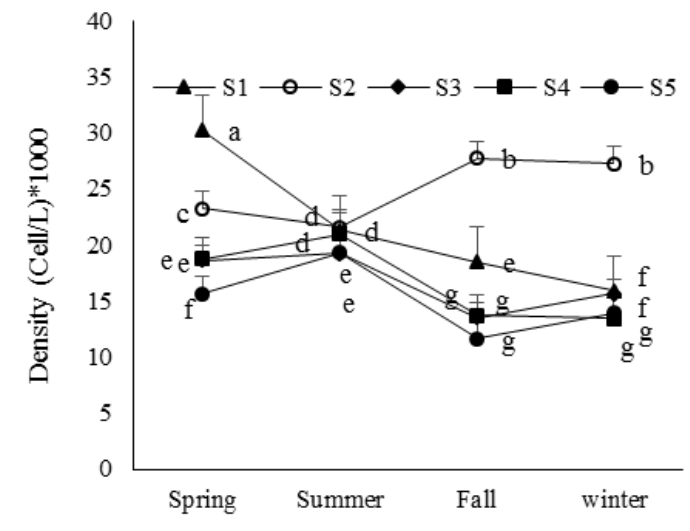

$\mathbf{E}$

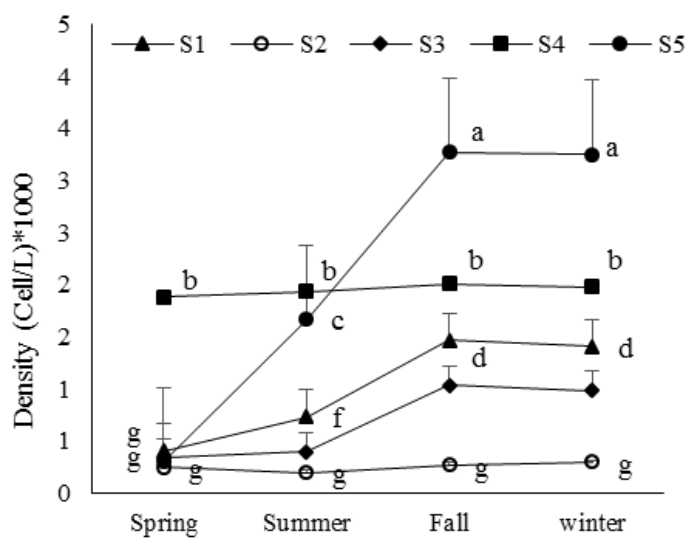

B

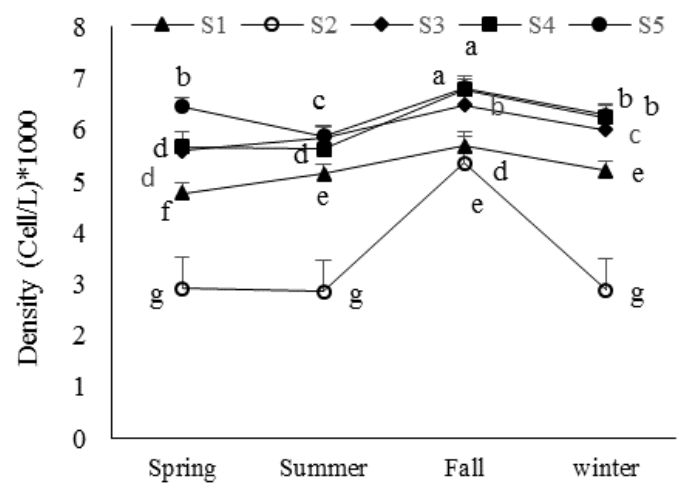

D

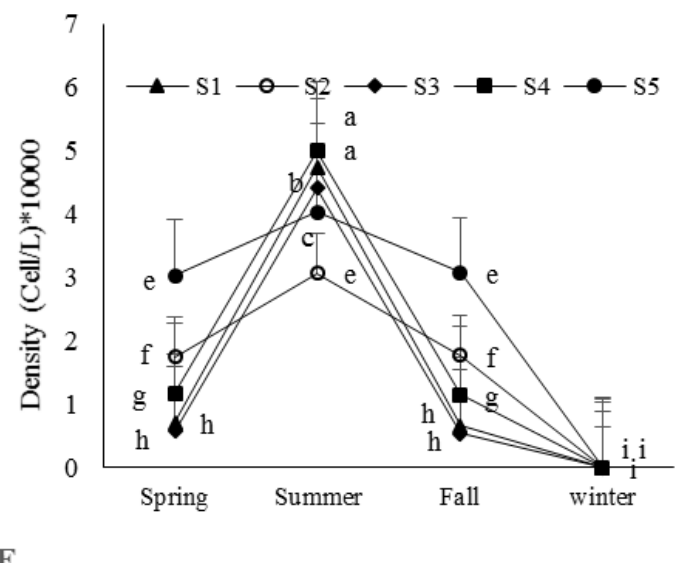

$\mathbf{F}$

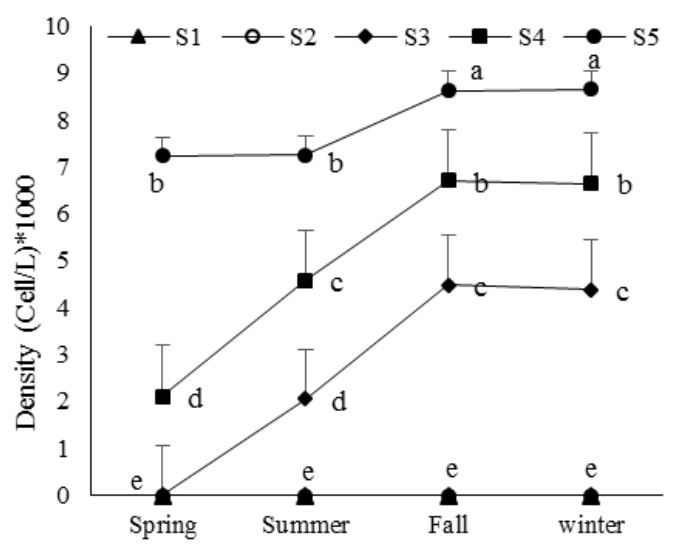

Figure 4. Density of different divisions: Chlorophyta (A), Cyanophyta (B), Bacillariophyta $(C)$, Dinophyta $(D)$, Euglenophyta $(E)$ and Chrysophyta $(F)$ in different seasons and stations (S1 -

$S 5)$ in the Choghakhor wetland. Data represent the means values $+S E(n=3)$. Different letters in the mean values indicated difference between the means based on Duncan's multiple range tests, $P<0.05$ 


\section{Phytoplankton diversity}

The phytoplankton diversity index $\left(\mathrm{H}^{\prime}\right)$ in different stations and seasons was different and was more than 3 ( $\mathrm{P}<0.05$ ) (Fig. 3). S4, S3 and S5 had highest diversity $(3.55,3.51$ and 3.50, respectively). The diversity index of $\mathrm{S} 1$ was 3.46 while in $\mathrm{S} 2$ was least (3.35). Also, phytoplankton diversity was highest in the summer (3.52) followed by winter (3.51), fall (3.45) and spring (3.414).

In $\mathrm{S} 5, \mathrm{~S} 3$ and $\mathrm{S} 2, \mathrm{H}^{\prime}$ was changed similarly as it was highest in the summer followed by winter, fall and spring. In $\mathrm{S} 1, \mathrm{H}^{\prime}$ in the winter was maximum followed by the summer, fall and spring. $\mathrm{H}^{\prime}$ in $\mathrm{S} 4$ did not change during the year.

Pearson correlation coefficient was shown in Table 7 to compare the correlations between physicochemical parameters of water and phytoplankton density and diversity.

Table 7. Pearson correlation coefficient between the total density and diversity $\left(H^{\prime}\right)$ of phytoplankton, density of Chlorophyta (Chl.), Cyanophyta (Cya.), Bacillariophyta (Bac.), Dinophyta (Din.), Euglenophyta (Eug.) and Chrysophyta (Chr.) with physico-chemical parameters (T: temperature, DO: dissolved oxygen, $\mathrm{pH}, \mathrm{N}$ : nitrate concentration and $\mathrm{P}$ : phosphate concentration) of water in the Choghakhor wetland

\begin{tabular}{c|c|c|c|c|c|c|c|c|c|c|c|c|c}
\hline & Density & $\mathbf{H}^{\prime}$ & $\mathbf{T}$ & $\mathbf{D O}$ & $\mathbf{p H}$ & $\mathbf{N}$ & $\mathbf{P}$ & Chl. & Cya. & Bac. & Din. & Eug. & Chr. \\
\hline & 1 & & & & & & & & & & & & \\
Density & -0.2 & 1 & & & & & & & & & & & \\
$\mathbf{H}$ & 0.2 & $-0.7^{* *}$ & 1 & & & & & & & & & & \\
DO & 0.2 & $0.5^{* *}$ & $-0.7^{* *}$ & 1 & & & & & & & & & \\
pH & 0.1 & $-0.7^{* *}$ & $-0.9^{* *}$ & $-0.7^{* *}$ & 1 & & & & & & & & \\
$\mathbf{N}$ & $0.6^{* *}$ & 0.2 & $-0.3^{*}$ & $0.7^{* *}$ & $-0.3^{*}$ & 1 & & & & & & & \\
$\mathbf{P}$ & 0.2 & $0.4^{* *}$ & $-0.5^{* *}$ & $0.9^{* *}$ & $-0.4^{* *}$ & $0.6^{* *}$ & 1 & & & & & & \\
Chl. & $0.9^{* *}$ & $0.3^{*}$ & -0.2 & $0.4^{* *}$ & $-0.2^{*}$ & $0.7^{* *}$ & $0.3^{* *}$ & 1 & & & & & \\
Cya. & $0.6^{* *}$ & $0.3^{* *}$ & -0.2 & $0.4^{* *}$ & $-0.2^{*}$ & $0.6^{* *}$ & $0.2^{*}$ & $0.6^{* *}$ & 1 & & & & \\
Bac. & $-0.4^{* *}$ & $-0.5^{* *}$ & $0.3^{*}$ & $-0.2^{*}$ & $0.3^{* *}$ & $-0.5^{* *}$ & -0.1 & $-0.7^{* *}$ & $-0.7^{* *}$ & 1 & & & \\
Din. & $0.3^{*}$ & $-0.8^{* *}$ & $0.8^{* *}$ & $-0.7^{*}$ & $0.8^{* *}$ & -0.2 & $-0.7^{* *}$ & -0.1 & 0.02 & 0.1 & 1 & & \\
Eug. & $0.2^{*}$ & $0.4^{* *}$ & $-0.3^{*}$ & 0.2 & $-0.2^{*}$ & $0.4^{* *}$ & -0.02 & $0.4^{* *}$ & $0.6^{* *}$ & $-0.6^{* *}$ & -0.1 & 1 & \\
Chr. & $0.6^{* *}$ & 0.1 & -0.2 & 0.1 & -0.1 & $0.4^{* *}$ & -0.1 & $0.6^{* *}$ & $0.7^{* *}$ & $-0.7^{* *}$ & 0.1 & $0.7^{* * *}$ & 1 \\
\hline
\end{tabular}

*Correlation is significant at the 0.05 level

**Correlation is significant at the 0.01 level

\section{Discussion}

\section{Variations in the physico-chemical parameters of water}

The results showed that S5 had highest nitrate concentration followed by S4, S3, S1 and S2 (Fig. 2A). Other studies on Choghakhor wetland has been shown that this wetland is affected by human activities including agricultural runoffs containing chemical fertilizers and residential wastewaters mostly in the southern and western parts (Ebrahimi and Moshari, 2006; Nadushan and Fatemi, 2008; Samadi, 2016). The residential wastewaters containing high nitrate concentration and phosphate (Khan and Ansari, 2005) has been caused to Choghakhor wetland pollution in south east and North West parts (Ebrahimi and Moshari, 2006; Nadushan and Fatemi, 2008; Samadi, 2016). It seems that the higher nitrate concentration in S5 and S4 may be due to the residential wastewaters leakage from Avorgan $\left(28387 \mathrm{~m}^{3}\right)$ and Sibak $\left(23433 \mathrm{~m}^{3}\right)$ villages into the stations. S3 and S1, are also received residential wastewaters from adjacent villages 
especially from Galugerd with the lower volume $\left(13208 \mathrm{~m}^{3}\right) . \mathrm{S} 2$ is located in the north of the wetland in the vicinity of the unutilized lands and so received minimum residential wastewater or agricultural runoff (Samadi, 2016). In fact, S2 can be considered as a control site to compare the effect of vicinity of the stations to residential and agricultural land uses on water quality and phytoplankton status. However, nitrate concentration in S2 was at least. Also, nitrate concentration in S5 and S4 in the fall and spring were more than the winter and summer. It may be due to the start of rainfall in the spring as well as fall, which causes leakage of residential wastewater flow from the adjacent regions to the wetland. The vicinity of S2 to unutilized lands was the reason for its lowest nitrate concentration than other stations in the spring and fall, in spite of rainfall. Accumulation of nitrate in the winter in S2, is likely related to less biochemical activities of macrophytes and less consumption of nitrate by them (Moss and Balls, 1989; Rana et al., 1995). Also, nitrate concentration was high in S2 in the summer due to less rainfall, rise of temperature which enhances decomposition followed by evaporation (Santhanam and Perumal, 2003). However, maximum concentration of nitrate was measured in S5 in the fall as well as the minimum in S2 in the spring (Fig. 2A).

Phosphate concentration was the highest in S3 followed by S5 and S4 and it was the lowest in S1 and S2. There are evidences supports that the Choghakhor wetland has been polluted by chemical farming fertilizers mainly containing high amounts of phosphate and to some extent nitrate in southwest (Ebrahimi and Moshari, 2006; Nadushan and Fatemi, 2008; Samadi, 2016) similar to other wetlands (Nassar and Gharib, 2014), especially. The vicinity of S3 to the farming lands leads to entry of agricultural runoffs containing much phosphate. Although S5 and S4 may receive less agricultural runoffs than S3, their phosphate content was remarkable (Fig. 2B). In S3 and S5, phosphate was highest in the fall and spring than other seasons due to more rainfall in theses seasons and consequently more leakage of the runoffs to this stations. Also in S1 and S2, maximum phosphate was measured in the summer followed by the winter as well as it was minimum in the spring followed by fall (Fig. 2B). It seems that raining in the fall and spring caused to dilution of the wetland water and low nutrient status. Also, highest phosphate in the summer in S2 may related to less rainfall, increase in temperature, decomposition enhancement followed by evaporation (Santhanam and Perumal, 2003). Also, phosphate concentration in S2 in the winter likely is because of less growth of macrophytes and less consumption of the phosphate due to higher share of macrophytes for phosphate absorption than phytoplankton (Rana et al., 1995; Moss, 2009).

The wetland water is completely alkaline throughout the year $(\mathrm{pH} \sim 8.78)$ as its $\mathrm{pH}$ was 9.55 in the summer and 8.12 in the winter and it was the same in different stations (Fig. 2C). Water temperature in different stations was similar and it was maximum in the summer and minimum in the winter (Fig. 2D). Dissolved oxygen of S4 and S5 was more than S1, S2 and S3 only in the winter. Also, dissolved oxygen was maximum in the winter and minimum in the summer (Watson et al., 1997). In fact, there were significant correlations between water physicochemical parameters (Table 7) (Peerapornpisal et al., 2004). There was a negative correlation between dissolved oxygen and temperature $(-0.7, \mathrm{P}<0.01)$ (Moss and Balls, 1989). Similarly, there was a negative correlation between $\mathrm{pH}$ and temperature $(-0.9, \mathrm{P}<0.01)$. Nitrate and phosphate concentration were negatively correlated with the $\mathrm{pH}(-0.3, \mathrm{P}<0.05$ and $-0.4, \mathrm{P}<0.01$, respectively). 


\section{Phytoplankton density}

Although different concentrations of nitrate and phosphate were measured in different stations (Fig. 2A, B), the total density of phytoplankton seems to be affected by variations in nitrate concentration, alone (Fig. $2 A$ ) because total phytoplankton density was positively correlated with nitrate concentration $(0.6, \mathrm{P}<0.01)$ and not correlated with phosphate concentration (Table 7) and also there was the highest total density in $\mathrm{S} 5$ in the fall or spring and the lowest in $\mathrm{S} 2$ in spring and in S1 in fall (Fig. 3). As previously mentioned, $\mathrm{S} 2$ was considered as control because of its more distance to residential and farming land uses as well as any leakage of the polluted runoffs, unlike the S5. In fact, the vicinity of S5 by the residential regions caused to increase nitrate content especially in rainfall seasons and consequently to increased total density of the phytoplankton.

The result also showed that the Chlorophyta density (Fig. 4), nitrate and phosphate concentration (Fig. $2 A$ and $B$ ) in S2 was less than S5. Also, there was correlations between Chlorophyta density and dissolved oxygen $(\mathrm{r}=0.4, \mathrm{P}<0.01), \mathrm{pH}(\mathrm{r}=-0.2$, $\mathrm{P}<0.05)$, nitrate $(\mathrm{r}=0.7, \mathrm{P}<0.01)$ and phosphate concentration $(\mathrm{r}=0.3, \mathrm{P}<0.01)$. Perhaps, high phosphate and nitrate concentrations in S5 may be the reason for high density of Chlorophyta in this station. Similarly, other studies has been shown that physico-chemical factors such as phosphate, nitrate, temperature and dissolved oxygen support the growth of Chlorophyta (Rana and Nirmal Kumar, 1992; Hegde and Sujata, 1997; Nirmal Kumar et al., 2005).

Also, the density of Chlorophyta, in S2 - as control station- in the winter and summer was higher than fall and spring while in S3, S4 and S5 - as polluted stations by nitrate and phosphate- it was higher in the fall and spring than winter and summer (Fig. 4). This difference may be related to the accumulation of the nutrients in $\mathrm{S} 2$, in the winter due to less biochemical activity and in the summer due to evaporation and less rainfall in these seasons. These results were similar to a previous work (Kumar and Oommen, 2011).

Accumulation of nitrate and phosphate in S5 in the fall and spring was due to rainfall in these seasons and leakage of the nutrients from adjacent polluted lands to these stations which caused to increase the density of Chlorophyta. In this study, an increase in the frequency of Chlorophyta at station 5 corresponds to the results obtained by Zębek and Szymańska (Zębek and Szymańska, 2017)

According to the correlation coefficients were observed between Cyanophyta density and dissolved oxygen content $(\mathrm{r}=0.4, \mathrm{P}<0.01), \mathrm{pH}(\mathrm{r}=-0.2, \mathrm{P}<0.05)$, nitrate $(\mathrm{r}=0.6$, $\mathrm{P}<0.01)$ and phosphate concentration $(\mathrm{r}=0.2, \mathrm{P}<0.01)$, the highest density of Cyanophyta which was observed in S5 may be related to the pollution of S5 by nitrate and phosphate especially in the rainy seasons of fall and spring. Inversely, the Cyanophyta density was at least in S2 (as control station) due to S2 vicinity to unutilized regions and lack of pollution by nitrate and phosphate (Fig. 4). Williams and Tonnessen stated that increased concentration of nitrate and phosphate caused to increase in phytoplankton density in water due to the essential role of nitrogen and phosphorous for phytoplankton activity (Williams and Tonnessen, 2000). The main consequence for enrichment of surface waters by nitrate and phosphorus is eutrification (Stoddard, 1994; Khan and Ansari, 2005). One of the indications for eutrification is the growth of Cyanophyta or green-blue algae which causes to water appears greenish. They assimilate phosphate at a faster rate than green algae (Lam and Silvester, 1979). 
Bacillariophyta density in S2 was more than S5 (Fig. 4) which is likely due to the lower concentration of nitrate in $\mathrm{S} 2$. There was a negative correlation between Bacillariophyta density and nitrate concentration ( $\mathrm{r}=-0.5, \mathrm{P}<0.01$, (Table 7). Due to dominance of Bacillariophyta in the lakes with less pollution (Song et al., 2007), so the lowest abundance of Bacillariophyta in S5 represents highest pollution of the wetland in this station. Also, Bacillariophyta is the most algal taxonomic group represented in mesotrophic systems (Rosén, 1981) such as S2 in our work.

The highest density of Dinophyta was observed in S5 followed by S3 (Fig. 4) while phosphate concentration was highest in S3 followed by S5 (Fig. 2A). Higher concentration of phosphate in S3 than S5 was related to agricultural runoffs entry to the station due to it vicinity to farming lands. So, considering negative correlation between the Dinophyta density and phosphate $(\mathrm{r}=-0.7, \mathrm{P}<0.01)($ Table 7$)$, the vicinity of S3 to farming lands may be a main factor to receive more phosphate and less growth of Dinophyta. Watson and colleague (1997) believe that in eutrophic regions (such as S3 and S5 in our work) Dinophyta generally decline (Watson et al., 1997).

Also, Dinophyta in the summer were most frequent than other seasons and they were not found in the winter in any stations (Fig. 4). This is because of highest temperature $(\mathrm{r}=0.8, \mathrm{P}<0.01)$ and $\mathrm{pH}(\mathrm{r}=0.8, \mathrm{P}<0.01)$ as well as lowest dissolved oxygen $(\mathrm{r}=-0.7, \mathrm{P}<0.05)$ in the summer (Fig. 2C, D and E) (Table 7) which caused to more growth of Dinophyta.

Euglenophyta and Chrysophyta in S5 were more abundant than other stations (Fig. 4). In S2, Euglenophyta was at least and Chrysophyta was absent in all seasons. There were positive correlations between the nitrate concentration and density of Euglenophyta as well as Chrysophyta $(\mathrm{r}=0.4, \mathrm{P}<0.01)$ (Table 7). Higher content of nitrate in S5 -due to the vicinity to residential regions- may be main factor to increase Euglenophyta and Chrysophyta in S5. Due to negative correlation between Euglenophyta density and $\mathrm{pH}(-0.2, \mathrm{P}<0.05)$ (Table 7) it seems that higher density of Euglenophytain in the winter (Fig. 4) is related to the lower $\mathrm{pH}$ in this season (Fig. 2C).

\section{Phytoplankton diversity}

The diversity indices $\left(\mathrm{H}^{\prime}\right)$ in $\mathrm{S} 4, \mathrm{~S} 3$ and $\mathrm{S} 5$ (3.55, 3.51 and 3.50, respectively) were not significantly different ( $\mathrm{P}<0.05)$ (Fig. 3) and were more than S1 and S2 (3.46 and 3.35 , respectively). Table 7 showed a positive correlation between total diversity of phytoplankton and phosphate concentration $(\mathrm{r}=0.4, \mathrm{P}<0.01)$. Therefore, higher phosphate concentration in polluted stations (S3, S4 and S5) may be the cause of greater diversity of phytoplankton than S1 and S2. Also, Diversity was highest in the summer (3.52) followed by winter (3.51), fall (3.45) and spring (3.414) which is due to the change in diversity of different divisions during the seasons. For example, Dinophyta in the summer were most frequent than other seasons and they were not found in the winter in any stations. Chrysophyta in S1 and S2 was absent.

The normal range of $\mathrm{H}^{\prime}$ is from 0 to 4 and indicated the diversity value and pollution status of a water body. The values $>3,1-3$ and $<1$ indicate clean water, moderate pollution and heavily polluted, respectively (Williams and Tonnessen, 2000). In this study, Shannon diversity index $\left(\mathrm{H}^{\prime}\right)$ ranged from 3.28 up to 3.57 and it was clear that the wetland water was still clean. Higher concentration of phosphate causes more diversity of individual taxonomic groups (Watson et al., 1997) which is similarly observed in S5. 


\section{Phytoplankton composition}

In this study, 59 genera and 43 families belonging to 6 divisions were identified which Bacillariophyta phylum and Nitzschia genus were the most common ones by the abundances of $46.6 \%$ and $14.8 \%$, respectively (Table 2 and 3-6). Similar result has been obtained by Arimoro et al. (2008). In each division, the highest density was recorded in the genus Nitzschia (Bacillariophyta, $6054 \pm 1915$ cell/L) as a bio-indicator for eutrophic status of the water, followed by Cosmarium (Chlorophyta, $2869 \pm 1855$ cell/L) as an oligotrophic status bio-indicator, Microcystis (Cyanophyta, $1969 \pm 714$ cell/L) as an eutrophic status bio-indicator, Peridinium (Dinophyta, $1293 \pm 1310$ cell/L), Euglenaria (Euglenophyta, $717 \pm 605$ cell/L) and Dinobryon (Chrysophyta, $314 \pm 337$ cell/L) (Tables 3, 4 and 6) (Wu, 1984; Sakset and Chankaew, 2013; Bellinger and Sigee, 2015). Also, the genus Pinnularia (Bacillariophta, $743 \pm 237$ ) is indicated an oligotrophic status while Cyclotella (Bacillariophyta, $2544 \pm 967$ cell/L), Anacystis (Cyanophyta, $925 \pm 405$ cell/L) and Surirella (Bacillariophyta, $557 \pm 178$ cell/L) indicating mesotrophic status of the wetland (Song et al., 2007; Fonge et al., 2012). Considering the highest density of the genus Microcystis indicating eutrophication in S5, S4 and S3 (Fig. 5) and due to the variations of nitrate and phosphate concentration in these stations (Fig. $2 A$ and B), it seems that the high nutrient content in the stations especially nitrate and phosphate caused to initiate eutrophic status in the wetland. In fact, the vicinity of these stations to the residential and agricultural land uses caused to the high nutrient concentrations specially in the raining seasons of the fall and spring.
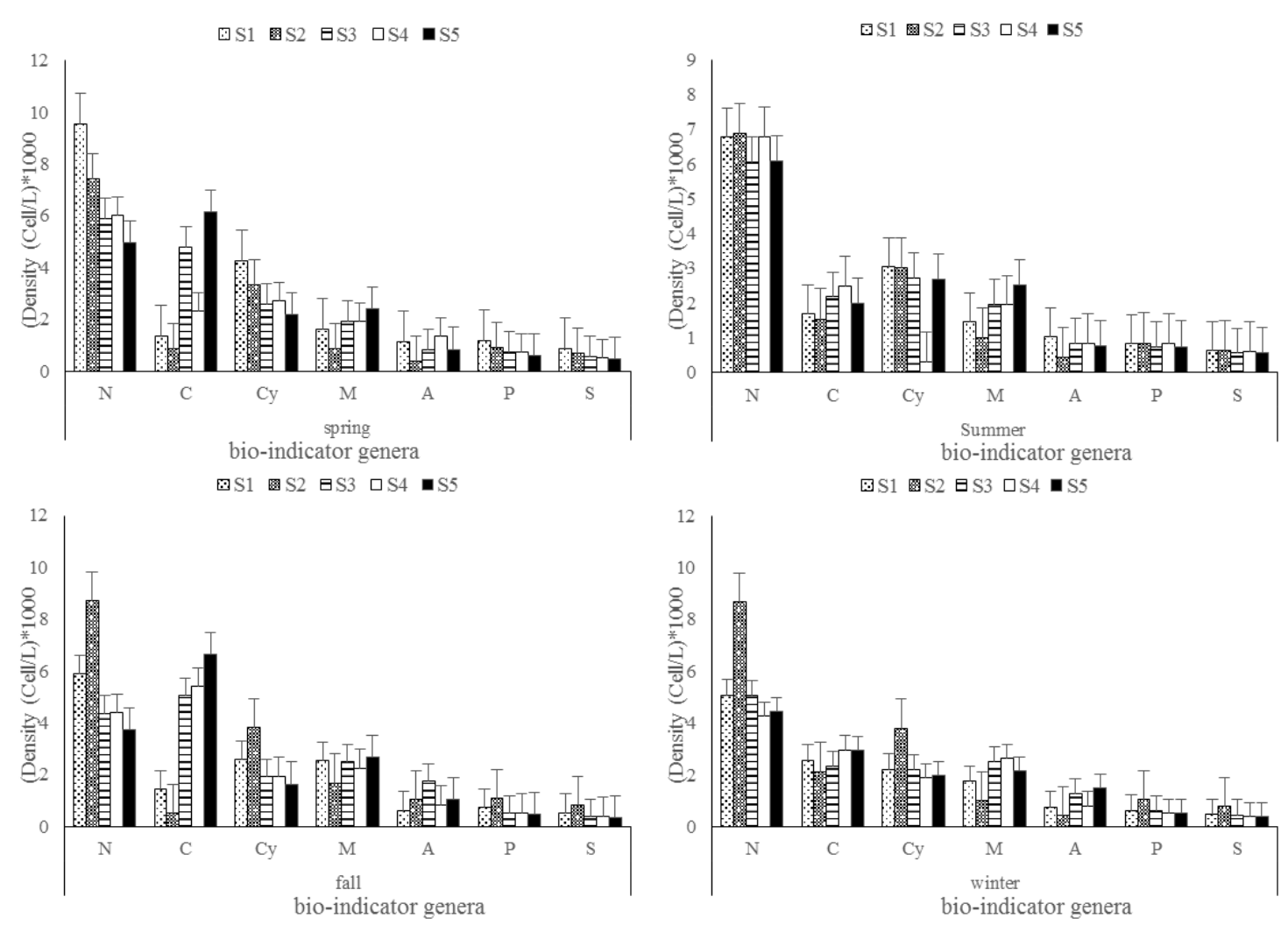

Figure 5. Composition of the bio-indicator genera (N: Nitzschia, C: Cosmarium, Cy: Cyclotella, M: Microcystis, A: Anacystis, P: Pinnularia, S: Surirella) for water trophic status in different stations and seasons in Choghakhor wetland 
Considering a positive correlation between the Cyanophyta density and nitrate (0.6, $\mathrm{P}<0.01)$ as well as phosphate concentration $(0.2, \mathrm{P}<0.05)$ (Table 7$)$ the Microcystis as the most abundant genus of Cyanophyta must be seriously controlled due to its ability to develop bloom in the wetland and to produce toxic compounds which threat the life of the organism living in the wetland (Lam and Silvester, 1979).

The total density of bio-indicator genera for eutrophic, oligotrophic and mesotrophic status were $8023 \pm 2888,3612 \pm 1503$ and $4026 \pm 1057$ cell/L, respectively. Although, $\mathrm{H}^{\prime}$ index was greater than 3 and so indicating the wetland water is clean, but according to the greater density of bio-indicator genera for eutrophic status, it seems that the wetland moves from mesotrophic and oligotrophic to the eutrophic status. It may be caused by the human activity mainly residential wastewaters and farming runoffs which makes entry of nitrate and phosphate to the adjacent parts of the wetland through the rainfall.

\section{Conclusion}

The phytoplankton status in relation to physico-chemical changes were evaluated in different seasons of 2011 as well as different stations in the margin of Choghakhor wetland. The stations were: S1 in north west affected by residential wastewaters; S2 in the north was adjacent to un-utilized regions (control); S3 in southwest was receiving agricultural runoffs; S4 and S5 in south east get residential wastewaters.

Phytoplankton community was included 59 genera, 43 families and 6 divisions which Bacillariophyta was the most common (46.6\%) with 25 genera followed by Chlorophyta (32.0\%), Cyanophyta (13.3\%), Dinophyta (4.4\%), Euglenophyta $(3.0 \%)$ and Chrysophyta $(0.8 \%)$. The most abundant genus was Nitzschia (14.8\%) from Bacillariaceae.

Phytoplankton density $(\mathrm{S} 5>\mathrm{S} 4>\mathrm{S} 3>\mathrm{S} 1>\mathrm{S} 2)$, as well as nitrate $(\mathrm{S} 5>\mathrm{S} 4>\mathrm{S} 3>$ $\mathrm{S} 1>\mathrm{S} 2)$ and phosphate $(\mathrm{S} 3>\mathrm{S} 5>\mathrm{S} 4>\mathrm{S} 1 \approx \mathrm{S} 2)$ were different in different stations and seasons $(\mathrm{P}<0.05)$. Also, there were correlations between phytoplankton density and nitrate $(\mathrm{r}=0.6, \mathrm{P}<0.01)$, Chlorophyta density and phosphate $(\mathrm{r}=0.3, \mathrm{P}<0.01)$, Cyanophyta density and phosphate $(\mathrm{r}=0.2, \mathrm{P}<0.05)$ which supports the nitrate and phosphate role to increase the density of the phytoplankton in the stations with high nutrient contents (S5, S4 and S3). Chlorophyta and Cyanophyta abundance were maximum in S5 and minimum in S2. Inversely, Bacillariophyta density was highest in S2 and lowest in S5. The highest and lowest density of Dinophyta was observed in S5 and S3, respectively. In S5, It was greater than S2. Dinophyta in the summer were most frequent than other seasons. Euglenophyta was most abundant in S5 and least abundant in S2. Chrysophyta in S5 was most abundant and in S2 was absent.

The composition of the genera within the divisions showed that the highest density was recorded in the genus Nitzschia (Bacillariophyta, eutrophic status bio-indicator), followed by Cosmarium (Chlorophyta, oligotrophic status bio-indicator), Microcystis (Cyanophyta, eutrophic status bio-indicator), Peridinium, Euglenaria and Dinobryo. Also, Microcystis was maximum in S5 followed by S4 and S3. Generally, the total density of bio-indicator genera for eutrophic, oligotrophic and mesotrophic status were $8023 \pm 2888,3612 \pm 1503$ and $4026 \pm 1057$ cell/L, respectively.

Mean diversity index was varied as: $\mathrm{S} 4 \approx \mathrm{S} 3 \approx \mathrm{S} 5>\mathrm{S} 1 \approx \mathrm{S} 2(\mathrm{P}<0.05)$ and represented that the wetland water is still clean $\left(\mathrm{H}^{\prime}>3\right)$. Although, $\mathrm{H}^{\prime}$ index was greater than 3 and so indicating the wetland water is clean, but according to the greater density 
of bio-indicator genera for eutrophic status, it seems that the wetland moves from mesotrophic and oligotrophic to the eutrophic status. It may be caused by the human activity mainly residential wastewaters and farming runoffs which makes entry of nitrate and phosphate to the adjacent parts of the wetland through the rainfall.

\section{REFERENCES}

[1] Amy, G., Sierka, R., Bedessem, J., Price, D., Tan, L., Beker, W., Chiang, P., Chang, E., Liang, C., Crozes, G. (1992): Standard methods for the examination of water and wastewater. - Pakistan Journal of Biological Sciences 9(4): 67-75.

[2] Arimoro, F., Edema, N. E., Amaka, R. O. (2008): Phytoplankton community responses in a perturbed tropical stream in the Niger Delta, Nigeria. - Tropical Freshwater Biology 17(1): 37-52.

[3] Bellinger, E. G., Sigee, D. C. (2015) Freshwater Algae: Identification and Use as Bioindicators. - John Wiley \& Sons, Chichester.

[4] Bressler, D. W., Paul, M. J. (2018): Effects of Eutrophication on Wetland Ecosystems. - [On-line]. [date of reference June 10th 2016]. Available at: https://www.researchgate.net/profle/David_Bressler/publication/252291163_effect s_of_eutrophication_on_wetland_ecosystems/links/551ed2860cf29dcabb083b03.pdf.

[5] Chang, F. H. (1995): The First Toxic Shellfish Outbreaks and the Associated Phytoplankton Blooms in Early 1993 in New Zealand. - In: Lassus, P., Erard, E., Gentien, P., Marcaillou, C. (eds.) Harmful Marine Algal Bloom. Springer, Berlin, pp. 145-150.

[6] Ebrahimi, S., Moshari, M. (2006): Evaluation of the Choghakhor Wetland Status with the Emphasis on Environmental Management Problems. - Publications of the Institute of Geophysics, Polish Academy of Sciences, Warsaw.

[7] Eloranta, P. (1986): Phytoplankton structure in different lake types in central Finland. - Holarctic Ecology: 214-224.

[8] Fonge, B., Tening, A., Egbe, E., Yinda, G., Fongod, A., Achu, R. (2012): Phytoplankton diversity and abundance in Ndop wetland plain, Cameroon. African Journal of Environmental Science and Technology 6(6): 247-257.

[9] Hegde, G., Sujata, T. (1997): Distribution of planktonic algae in three freshwater lentic habitats of Dharwad. - Phykos 36(1-2): 49-53.

[10] Hou, D., He, J., Lü, C., Sun, Y., Zhang, F., Otgonbayar, K. (2013): Effects of environmental factors on nutrients release at sediment-water interface and assessment of trophic status for a typical shallow lake, Northwest China. - The Scientific World Journal 2013: 716342-716342.

[11] Jones, C. G., Lawton, J. H., Shachak, M. (1996): Organisms as Ecosystem Engineers. - In: Samson, F. B. (Ed.) Ecosystem Management: Selected Readings. Springer, New York, pp. 130-147.

[12] Kelly, M. (1998): Use of the trophic diatom index to monitor eutrophication in rivers. - Water Research 32(1): 236-242.

[13] Khan, F. A., Ansari, A. A. (2005): Eutrophication: an ecological vision. - The Botanical Review 71(4): 449-482.

[14] Krammer, K., Lange-Bertalot, H. (1986): Bacillariophyceae. Süsswasserflora von Mitteleuropa 2 (1-4). - VEB G. Fischer Verlag, Jena.

[15] Kumar, N., Oommen, C. (2011): Phytoplankton composition in relation to hydrochemical properties of tropical community wetland, Kanewal, Gujarat, India. - Applied Ecology and Environmental Research 9(3): 279-292. 
[16] Lam, C. W., Silvester, W. B. (1979): Growth interactions among blue-green (Anabaena oscillarioides, Microcystis aeruginosa) and green (Chlorella sp.) algae. - Hydrobiologia 63(2): 135-143.

[17] Magurran, A. E. (1988) Ecological Diversity and Its Measurement. - Princeton University Press, Princeton, NJ.

[18] Moss, B., Balls, H. (1989): Phytoplankton distribution in a floodplain lake and river system. II Seasonal changes in the phytoplankton communities and their control by hydrology and nutrient availability. - Journal of Plankton Research 11(4): 839-867.

[19] Moss, B. R. (2009): Ecology of Fresh Waters: Man and Medium, Past to Future. John Wiley \& Sons, Chichester.

[20] Muhammad, A., Abdus, S., Sumayya, I., Tasveer, Z., Kamran, A. (2005): Studies on monthly variations in biological and physico-chemical parameters of brackish water fish Pond, Muzaffar Garh, Bahauddin Zakariya University, Multan, Pakistan. - Pak. J. Res. Sci 16(1): 27-38.

[21] Nadushan, R. M., Fatemi, S. (2008): Trophic status and primary production in Lake Choghakhor, Chaharmahal-Bakhtiyari Province, Islamic Republic of Iran. Pakistan Journal of Biological Sciences PJBS 11(4): 577-582.

[22] Nassar, M. Z. A., Gharib, S. M. (2014): Spatial and temporal patterns of phytoplankton composition in Burullus Lagoon, Southern Mediterranean Coast, Egypt. - The Egyptian Journal of Aquatic Research 40(2): 133-142.

[23] Nirmal Kumar, J., Kumar, R. N., Bhatt, I. (2005): Study of Cultural Eutrophication in Relation to Plant Diversity of Wetland: Ratheshwar in Central Gujarat. - In: Khanna, D. R. et al. (eds.) Aquatic Biodiversity in India: The Present Scenario. Daya, Delhi.

[24] Peerapornpisal, Y., Chaiubol, C., Pekkoh, J., Kraibut, H., Chorum, M., Wannathong, P., Ngernpat, N., Jusakul, K., Thammathiwat, A., Chuananta, J. (2004): The monitoring of water quality in Ang Kaew Reservior of Chaing Mai University by using phytoplankton as bioindicator from 1995-2002. - Chiang Mai University Journal of Natural Sciences 31(1): 85-94.

[25] Rana, B., Nirmal Kumar, J. (1992): Macrophytes and nutrient study of two wetlands of Guajrat, India. - International Journal Ecology and Environmental Science 18: 195-202.

[26] Rana, B., Kumar, J. N., Sreenivas, S. (1995): Phytoplankton Ecology of Certain Water Bodies of Gujarat, India. - In: Kargupta, A. N., Siddique, E. N. (eds.) International Book Distributors, Deharadun, India, pp. 101-129.

[27] Rosén, G. (1981): Phytoplankton indicators and their relations to certain chemical and physical factors. - Limnologica Journal 13(2): 263-290.

[28] Rosińska, J., Kozak, A., Dondajewska, R., Gołdyn, R. (2017): Cyanobacteria blooms before and during the restoration process of a shallow urban lake. - Journal of Environmental Management 198: 340-347.

[29] Sahu, G., Satpathy, K., Mohanty, A., Sarkar, S. (2012): Variations in community structure of phytoplankton in relation to physicochemical properties of coastal waters, southeast coast of India. - Iranian Journal of Medical Sciences 41 (3): 223241.

[30] Sakset, A., Chankaew, W. (2013): Phytoplankton as a bio-indicator of water quality in the freshwater fishing area of Pak Phanang River Basin (Southern Thailand). - Chiang Mai University Journal of Natural Sciences 40(3): 344-355.

[31] Samadi, J. (2016): Survey of spatial-temporal impact of quantitative and qualitative of land use wastewaters on Choghakhor wetland pollution using IRWQI index and statistical methods. - Iran-Water Resources Research (IR-WRR) 11(3): 159-171. 
[32] Santhanam, P., Perumal, P. (2003): Diversity of zooplankton in Parangipettai coastal waters, southeast coast of India. - Journal of Marine Biology Association of India 45(2): 144-151.

[33] Sinha, V., Srivastava, H. (1991): Aquaculture Productivity. - Oxford and IHB Publishing Co. Pvt. Ltd., New Delhi.

[34] Song, X., Liu, Z., Pan, H., Yang, G., Chen, Y. (2007): Phytoplankton community structure in Meiliang Bay and lake Wuli of lake Taihu. - Journal of Lake Sciences 19(6): 643-651.

[35] Sorayya, M., Aishah, S., Sapiyan, B. M., Mumtazah, S. S. (2011): A self organizing map (SOM) guided rule based system for freshwater tropical algal analysis and prediction. - Scientific Research and Essays 6(25): 5279-5284.

[36] Stević, F., Kovačević, K., Čerba, D., Maronić, D. Š., Pfeiffer, T. Ž. (2018): Seasonal changes of phytoplankton in shallow floodplain lake. - 13. Hrvatski biološki kongres s međunarodnim sudjelovanjem.

[37] Stoddard, J. L. (1994): Long-Term Changes in Watershed Retention of Nitrogen, Its Causes and Aquatic Consequences. - In: Baker, L. A. (ed.) Environmental Chemistry of Lakes and Reservoirs. American Chemical Society, Washington, pp. 223-284.

[38] Watson, S. B., McCauley, E., Downing, J. A. (1997): Patterns in phytoplankton taxonomic composition across temperate lakes of differing nutrient status. Limnology and Oceanography 42(3): 487-495.

[39] Williams, M. W., Tonnessen, K. A. (2000): Critical loads for inorganic nitrogen deposition in the Colorado Front Range, USA. - Ecological Applications 10(6): 1648-1665.

[40] Wu, J. (1984): Phytoplankton as bioindicator for water quality in Taipei. Botanical Bulletin of Academia Sinica 25(2): 205-214.

[41] Zębek, E., Szymańska, U. (2017): Abundance, biomass and community structure of pond phytoplankton related to the catchment characteristics. - Knowledge \& Management of Aquatic Ecosystems 418: 45.

[42] Zhang, P. (2018): Trophic interactions in warming waters: aquatic plant-consumer interactions under climate change. - PhD Thesis, University Utrecht. 